
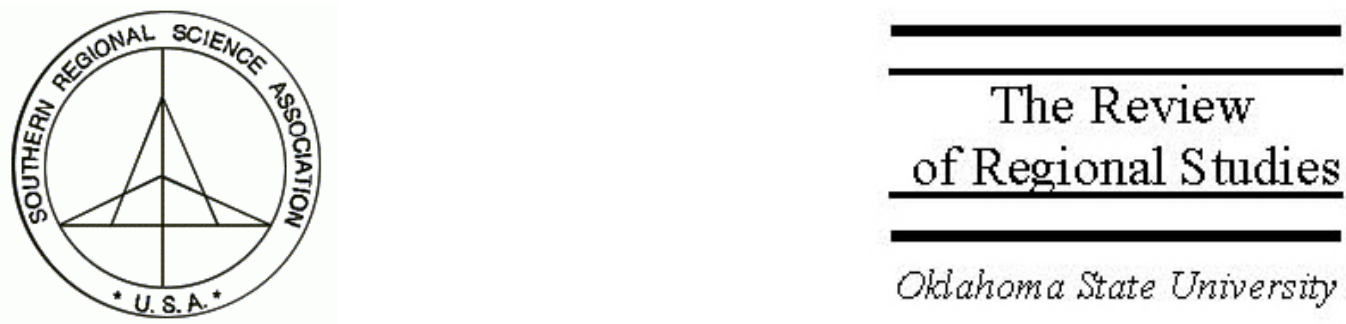

\title{
Food Industry Investment Flows: Implications for Rural Development
}

\author{
Dayton M. Lambert \\ Department of Agricultural Economics, University of Tennessee, 302 Morgan Hall, \\ Knoxville, TN 37996-4518, e-mail: dmlambert@tennessee.edu
}

Kevin T. McNamara

Department of Agricultural Economics, Purdue University, 403 West State Street, Krannert Building, West Lafayette, IN 47907-2056, e-mail: mcnamara@purdue.edu

\section{Megan I. Garrett}

Boomtown Institute, Effingham, IL 62401, e-mail:mbeeler@boomtowninstitute.com

\begin{abstract}
Food processing firms are often seen as potential sources of growth for rural areas. This paper examines the influence that agglomeration, labor, product and input markets, infrastructure, and government fiscal attributes have on food manufacturing investment flows. The analysis uses a spatial probit model along with spatial clustering methods to analyze county-level data for 12 states in the midwest and southern U.S. Findings suggest that rural areas are at a comparative disadvantage with respect to attracting demand-oriented food processors, but non-metro counties with economic ties to urban centers may be attractive investment sites to supply-oriented food manufacturers.

Keywords: Cluster analysis; Firm site selection; Food manufacturing; Spatial probit

JEL classification: $R 1 ; R 3$

The authors would like to thank Gerry Schluter, Carol Jones, Pat Sullivan, Tim Wojan, and Keith Wiebe for comments and suggestions on earlier versions of this manuscript, all with the Economic Research Service. We thank Shawn Bucholtz, also with ERS, for calculating the county perimeters used to construct the spatial weighting matrix. We also would like to thank the reviewers. The views expressed in this manuscript do not necessarily reflect those of our aforementioned colleagues, the University of Tennessee, Agracel, or Purdue University.
\end{abstract}




\section{INTRODUCTION}

As the economy continues to evolve under forces of globalization and increased international competition, the ability of rural areas to compete for manufacturing investment is unclear. Heightened competition, rapid adoption of new production and processing technologies, and an economy that has seen manufacturing employment decline at an annual rate of 0.2 percent nationally since 1960 have reduced the attractiveness of rural areas as locations for manufacturing (Barkley 1995; Goe 2002). Rural industrialization was fueled by the movement of manufacturing out of core urban areas to low-cost labor sites in the 1970s. Since the late 1990s, rural areas have struggled as manufacturing investment flows back to urban areas that provide access to skilled labor, business services, and product and input markets. The increased importance of labor skills and emphasis on scale economies has resulted in an increased concentration of manufacturing investment in urban areas (Amiti 1998; Black and Lynch 2000).

Rural areas have typically relied on a lower-cost, less-educated workforce to attract manufacturing investment of firms seeking to decrease wage costs (McGranahan 1998; Schluter and Lee 2002). However, concomitant with globalization is increased access to deeper labor markets, encouraging manufacturers to seek low-wage workers abroad. To the extent that information technologies and technological innovation drive productivity growth, low-skilled workforces and lack of business services have put many rural locations at a disadvantage with respect to attracting manufacturing investment.

But recruiting food processing plants still remains the focus of some rural economic development strategies in the belief that rural areas offer an access advantage to firms processing agricultural commodities (Testa 1993). Some state and local governments consider food manufacturing and other value-added agribusinesses as potential mechanisms to counteract rural population decline and unemployment because value-added agriculture activities are possible sources of off-farm employment and could increase farm income through backward linkages to local agricultural production (Capps, Fuller, and Nichols 1988; Barkema, Drabenstott, and Stanley 1990; Benirschka and Binkley 1994; Henderson and McNamara, 2000). While the renaissance in rural manufacturing ended in the 1980s, Schluter and Lee (2002) found that food processing still remains more rural-based than most U.S. manufacturing, suggesting that some rural communities have a comparative advantage over urban areas in attracting food manufacturing investment.

This paper examines the market factors and agglomeration, infrastructure, labor, and fiscal policy attributes influencing food manufacturing plant location decisions in the midwestern and southern states. A relevant policy question is: which communities in this region are positioned to successfully compete for food manufacturing investment? To answer this question, a model was developed to estimate (1) the factors influencing the likelihood that a food manufacturing firm locates operations in a given county, and (2) to isolate regional clusters of counties more likely to attract food manufacturing investment. By isolating counties more likely to attract food manufacturing investment and then 
comparing which attributes of those counties tend to drive the site selection decisions of potential investors, insight might be gained as to which factors local communities might focus scarce resources if they choose to pursue recruitment of food manufacturers as a development strategy.

To accomplish these objectives, predicted probabilities of firm-to-county location events generated by a limited dependent variable model are analyzed using local indices of spatial association (LISA, Anselin 1995), a spatial clustering technique. Product markets, agglomeration, infrastructure, and a skilled labor force are hypothesized to increase the comparative advantage of counties with respect to attracting food manufacturing investment. It is also hypothesized that non-metropolitan counties are more likely to attract supply-oriented food manufacturers, while demand-oriented food processors will be more likely to choose sites in or near metropolitan counties.

The next section provides an overview of the food industry and manufacturing location literature and the conceptual basis of the location model used to determine food manufacturer site selection. Section two describes the data and the empirical specifications of the models used to assess which factors are correlated with the site selection decision of food manufacturers. Using the predicted location probabilities, regions where food manufacturers with different cost structures are more likely to locate operations are identified using spatial cluster analysis. The results are reported and discussed in the last section, followed by conclusions and some implications for rural development.

\section{CONCEPTUAL MODEL}

Over the past century, U.S. food manufacturing has followed the westward movement of the population and product and input market expansion (Connor and Schiek 1997). Recent industrial plant location research suggests that manufacturing location choices are increasingly influenced by access to product and input markets, business services, and manufacturing agglomeration. Goetz (1997) and Henderson and McNamara (2000) examined food processor site selection and concluded that plant investments were influenced by the same factors that affected general manufacturing plant investment decisions: access to product and input markets, agglomeration economies, and infra-structure. And, like other sectors in manufacturing, food processing has also evolved with technological innovation (Connor and Schiek 1997). The integration of information technology into all aspects of firm operations coupled with intensified capitalization also suggests that firms will continue to become more concentrated in agglomeration economies (Barkley 1995). Food manufacturing location studies also find that proximity to markets, infrastructure, and labor characteristics are key location determinants (Lopez and Henderson 1989; Leistritz 1992; Vesecky and Lins 1995).

Food manufacturing plants have been broadly classified as "demand-oriented," "supply-oriented," or "footloose" on the basis of their cost structure (Connor and Schiek 1997; Henderson and McNamara, 1997). Henderson and McNamara (2000) found that food processor location depends on the cost structure of the firm. Sites are selected based 
on the availability of local resources to minimize the costs associated with production of specific food products. Demand-oriented firms are characterized by a total cost structure dominated by distribution costs. These firms typically produce fragile or perishable goods such as chips, ice-cream, and baked goods or bulky items such as beverages. Food processors whose cost structure is dominated by distribution costs will locate in areas where transport costs are minimized or places where product markets are easily accessed. Supply-oriented firms have a total cost structure dominated by the purchase of a single input commodity. These firms tend to locate near inputs to minimize procurement costs. For example, supply-oriented food manufacturers focusing on production of starches or oils choose sites with access to primary inputs such corn and other grain crops. Other examples of supply-oriented food manufacturers include meat packers, mills, and plant oil processors. Footloose firms have a cost structure not dominated by either demand or supply factors. Examples include firms that produce mixed nuts, confectionaries, chocolates, or salsa. These firms usually locate in areas with access to human or physical capital, transportation, and business services.

Plant location choice has been characterized as a two-stage decision process (Bartik 1985; Schmenner, Huber, and Cook 1987; McNamara, Kriesel, and Deaton 1988; Woodward 1992; Henderson and McNamara 1997; Lambert, McNamara, and Garrett 2006). Firms are hypothesized to evaluate potential sites on the basis of regional, state, local, and site-specific attributes. In the first stage, firms select a region based on broad company objectives such as access to raw materials, entrance into product markets, increasing market share, or other criteria in the firms' objective function. In the second stage, firms seek a minimum cost site within the selected region for their investment (Kriesel and McNamara 1991). The second stage of the location decision is represented as $\mathrm{S}=g(\mathrm{M}, \mathrm{A}, \mathrm{L}, \mathrm{I}, \mathrm{F})$, where $\mathrm{S}$ is the site location choice and $\mathrm{M}, \mathrm{A}, \mathrm{L}, \mathrm{I}, \mathrm{F}$ are vectors of community attributes representing input and product markets (M), agglomeration factors (A), labor attributes (L), infrastructure (I), and fiscal characteristics (F) that influence firm costs, respectively. The two stages of the location decision process are assumed to be independent of each other.

\section{SITE SELECTION AND LOCATION DETERMINANTS}

Food industry location decisions - or "investments" - are measured by a firm announcing plans to locate a new facility in the midwest-southern region of the United States (Figure 1) $(\mathrm{N}=1,121$ counties). Conway Industries, Inc., a firm involved in a variety of manufacturing industry-support activities, tracks manufacturing investment by sector throughout the United Sates. Conway data on county-level food industry plant location announcements for the 2000-2002 periods were used to measure food industry location activity. Food processors were classified as demand-oriented, supply-oriented, or footloose based on the industry's cost structure (i.e., the type of food the firm manufactured) using the Connor and Schiek (1997) typology. Conway does not follow up on the location announcements, so it is not known whether the firm actually went ahead and built a plant in a given county. But this is inconsequential since it is the local factors 


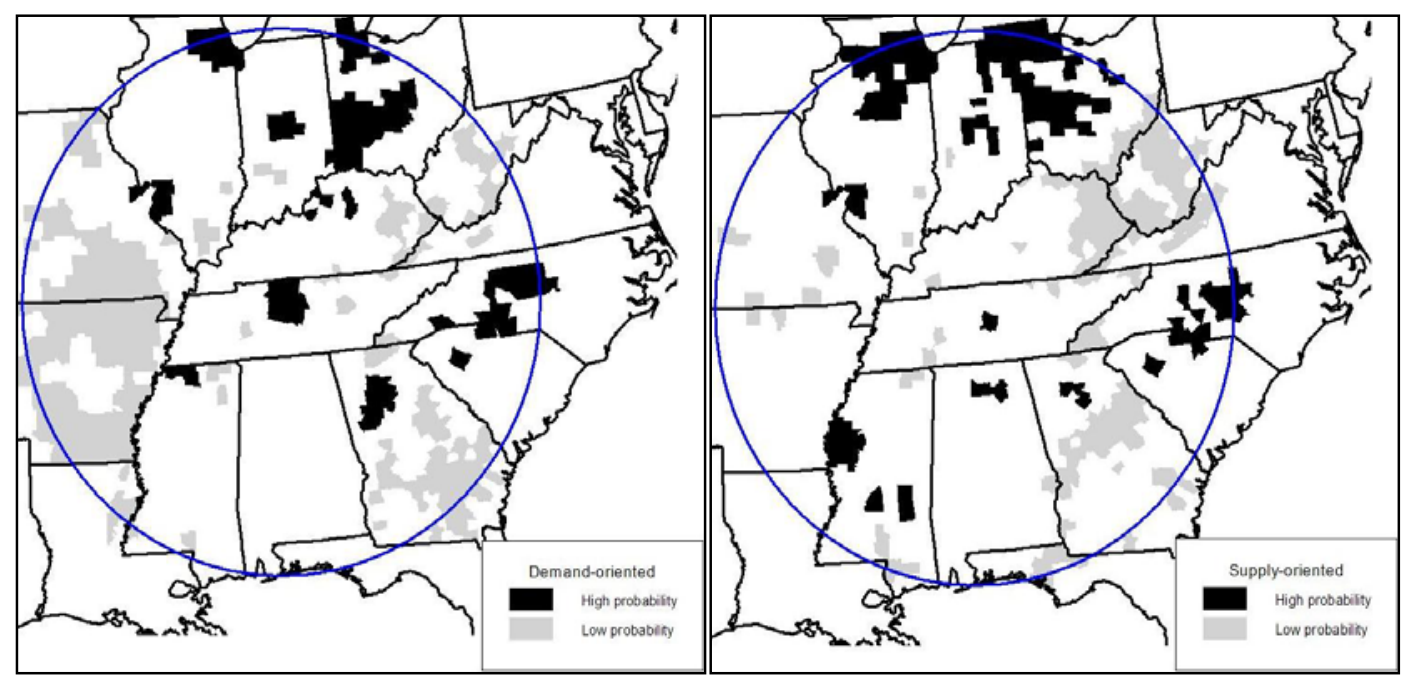

FIGURE 1. High and Low Site Selection Probability Clusters for Demandand Supply-Oriented Firms

Notes: High and low clusters are significantly different from all other counties at the $5 \%$ level. Source: authors' estimates.

associated with the county that attracted the firm in the first place that are of primary interest.

\subsection{Regions and Locations}

The midwestern and southern states defining the study area are considered the "regions" where food manufacturers choose to locate their operations. ${ }^{1}$ While it is unlikely that individual states are the actual regions considered by firms in the first stage of the location model, it is plausible to assume that states carry at least some of the information firms might find important for making a first-stage, regional-level location decision (Bartik 1985). States embody idiosyncrasies (such as fiscal or governing policy or availability of transport infrastructure) that may influence the first-stage selection of a region corresponding with company objectives. Other first-stage characteristics that may be represented by a state are resource endowments (such as access to navigable water-

\footnotetext{
${ }^{1}$ These include Michigan, Ohio, Illinois, Indiana, West Virginia, Virginia, Mississippi, Missouri, Alabama, Tennessee, Georgia, South Carolina, and Kentucky. A 500-mile radius was arbitrarily chosen, with Nashville, TN, the center. This point was chosen since: (1) it spans the region between the Great Lakes and the Gulf of Mexico; (2) the selected region exhibits remarkable variation with respect to population centers, product and input markets, agricultural lands, and diversity across economic sectors.
} 
ways, fertile land, or forestry products) or specialization in certain economic sectors or agricultural products (such as manufacturing in Indiana and Ohio, tobacco in North Carolina, or aquaculture in Mississippi). If the two-stage model is a tenable assumption, then coefficients associated with the regions should be uncorrelated, holding other factors constant, with second-stage location decisions. When the two-stage assumption is maintained (i.e., independence between the first and second stages), local factors influencing site selection can be isolated from the broader regional context, thereby providing a clearer idea about which community attributes are important with respect to attracting outside investment.

A distinction is made between metropolitan and non-metropolitan areas using the 2003 urban-rural classification system of the U.S. Census. This classification system is based partly on commuting flows into and out of counties. The 12 categories used to characterize the urban-rural county continuum were collapsed into three broad categories for tractability: metropolitan counties, micropolitan counties, and "non-core" or rural counties (Table 1). Metropolitan counties are defined as (1) central counties with one or more urbanized areas, or (2) outlying counties that are economically tied to the core counties as measured by commuting workers. Outlying counties are included if 25 percent of workers living in the county commute to the central counties or if 25 percent of the employment in the county consists of workers leaving the central counties - the so-called "reverse" commuting pattern. Micropolitan counties are non-metropolitan counties with 10,000 persons or more and are centers of broader micropolitan areas. Outlying counties are included in the definition if the percent of the workforce commuting out of (or into) the county is greater than 25 percent. All other counties are classified as non-core, rural counties. These counties have no urban clusters of 10,000 persons or more, less than 25 percent of the workforce commutes into or out of the county, and they are not adjacent to metropolitan counties. ${ }^{2}$

\subsection{Product and Input Markets (M)}

Access to input and product markets influences plant investment decisions. Bartik (1985) and Woodward (1992) found that access to markets had a positive effect on manufacturing location at the state level. Goetz (1997) found that access to product markets had a positive influence on food manufacturing firm location choice. Henderson and McNamara $(1997,2000)$ found that access to input and product markets influenced food manufacturing location choice at the county level. In their research, cash receipts for crops and livestock were used to measure access to inputs for food manufacturers.

\footnotetext{
${ }^{2}$ While any definition of "metro" versus "non-metro" is somewhat arbitrary, these categories retain some information about inter-county dependency in particular and broader regional economic linkages in general. Furthermore, they may be useful in some settings for helping local leaders or other policy makers understand their position in a wider regional context with respect to their competitiveness in recruiting outside firm investment. In the regression analysis, metropoli$\tan$ counties are the reference group. Further information about these definitions can be found at http://www.ers.usda.gov/Briefing/Rurality/MicropolitanAreas/.
} 
TABLE 1

Variable Description, Labels, and Summary Statistics of Location Determinants

\begin{tabular}{|c|c|c|c|c|c|}
\hline $\begin{array}{l}\text { LOCATION } \\
\text { DETERMINANTS } \\
\end{array}$ & DESCRIPTION & LABEL & MEAN & $\mathrm{CV}$ & $\begin{array}{l}\text { EXP. } \\
\text { SIGN }\end{array}$ \\
\hline & ----------------------------------------------------IN & EPENDENT V & IABLES- & ------- & \\
\hline \multirow{4}{*}{ Market (M) } & $\begin{array}{l}\text { Sum of crops and livestock cash receipts } \\
\text { per county acre, } 2000 \text { (dollars/acre) }\end{array}$ & AGRI $^{\mathrm{a}}$ & 342 & $123 \%$ & + \\
\hline & Population, 2000 & $\mathrm{POP}^{\mathrm{b}}$ & 60,453 & $313 \%$ & + \\
\hline & $\%$ farmland in county & PERFARM $^{f}$ & $47 \%$ & $55 \%$ & + \\
\hline & $\begin{array}{l}\text { Per capita personal income, } 2000 \\
(\$ / \text { person) }\end{array}$ & $\mathrm{PCI}^{\mathrm{a}}$ & 21,283 & $20 \%$ & + \\
\hline \multirow{3}{*}{ Agglomeration (A) } & $\begin{array}{l}\text { Food manufacturing establishments/total } \\
\text { number of establishments, } 2000(\%)\end{array}$ & MFGS $^{b}$ & $0.38 \%$ & $101 \%$ & + \\
\hline & $\begin{array}{l}\% \text { of labor force employed in } \\
\text { manufacturing }\end{array}$ & MEMPL $^{\mathrm{b}}$ & $18 \%$ & $53 \%$ & + \\
\hline & $\begin{array}{l}\% \text { change in total number of manufacturing } \\
\text { establishments, } 1998 \text { to } 2001\end{array}$ & $\mathrm{CHGMFG}^{\mathrm{b}}$ & $-0.04 \%$ & $490 \%$ & + \\
\hline \multirow{5}{*}{ Infrastructure (I) } & Interstate in the county $(1=$ yes $)$ & INTER $^{\mathrm{c}}$ & $45 \%$ & $41 \%$ & + \\
\hline & Land area in acres, $2000(10,000 \mathrm{~s}$ acres $)$ & LAND $^{\mathrm{c}}$ & 31.8 & $110 \%$ & + \\
\hline & $\begin{array}{l}\text { Technical school, junior college or } \\
\text { university present, } 2000(1=\text { yes })\end{array}$ & EDUC $^{b}$ & $37 \%$ & $130 \%$ & + \\
\hline & County next to river $(1=$ yes $)$ & RIVER $^{\mathrm{c}}$ & $27 \%$ & $165 \%$ & + \\
\hline & Amenity index (index) & AMENITY $^{\mathrm{e}}$ & -0.48 & $-307 \%$ & $+/-$ \\
\hline \multirow{4}{*}{ Labor (L) } & Unemployment rate $2000(\%)$ & UNEM $^{\mathrm{d}}$ & $7 \%$ & $38 \%$ & + \\
\hline & $\begin{array}{l}\% \text { of population over the age of } 25 \text { with } \\
\text { high school degree, } 2000\end{array}$ & $\mathrm{HIGH}^{\mathrm{b}}$ & $73 \%$ & $11 \%$ & $+/-$ \\
\hline & $\begin{array}{l}\text { Annual manufacturing wage per worker } \\
2000(\$ / \text { person })\end{array}$ & MWAGE $^{\mathrm{a}}$ & 27,732 & $62 \%$ & - \\
\hline & $\begin{array}{l}\% \text { of labor force employed in professional } \\
\text { or technical services, } 2000\end{array}$ & EMP54 ${ }^{\mathrm{b}}$ & $3 \%$ & $48 \%$ & + \\
\hline Fiscal Policy (F) & $\begin{array}{l}\text { Per capita property taxes/general } \\
\text { expenditures per capita, } 2000 \text { (ratio) }\end{array}$ & $\mathrm{TXEXC}^{\mathrm{b}}$ & 0.27 & $85 \%$ & - \\
\hline \multirow{2}{*}{ Non-metro counties } & Micropolitan county $(1=$ yes $)$ & MICRO $^{\mathrm{e}}$ & $25 \%$ & $175 \%$ & $+/-$ \\
\hline & Rural county $(1=$ yes $)$ & RURAL $^{\mathrm{e}}$ & $40 \%$ & $123 \%$ & $+/-$ \\
\hline FIRM TYPE /g & \multicolumn{5}{|c|}{ 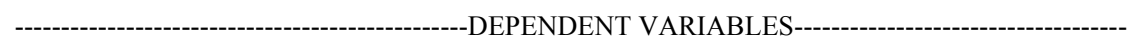 } \\
\hline ALL FIRMS & \multicolumn{2}{|l|}{$\%$ of counties in sample } & $22 \%$ & $187 \%$ & \\
\hline SUPPLY- & \multicolumn{2}{|l|}{$\%$ of counties in sample } & $9 \%$ & $320 \%$ & \\
\hline $\begin{array}{l}\text { DEMAND- } \\
\text { ORIENTED }\end{array}$ & \multicolumn{2}{|l|}{$\%$ of counties in sample } & $12 \%$ & $265 \%$ & \\
\hline $\begin{array}{l}\text { FOOTLOOSE } \\
\text { FIRMS }\end{array}$ & \multicolumn{2}{|l|}{$\%$ of counties in sample } & $7 \%$ & $274 \%$ & \\
\hline
\end{tabular}

Sources: a-Bureau of Economic Analysis; b-US Census Bureau;c-ESRI ArcView data files; dBureau of Labor Statistics; e- Economic Research Service; f -Ag Census 2002; g- Conway, Inc, 2000-2002. 
Firms enter input markets with the goal of minimizing input procurement costs. Firms seek locations that provide access to inputs and reduce transportation costs associated with the procurement of bulky, perishable, watery, or immovable resources (Connor 1987; Capps, Fuller, and Nichols 1988). But the relative importance of input access differs by the type of food processor. Access to raw material inputs may be more important for supply-oriented plants because their cost structure is dominated by costs associated with input acquisition. It is hypothesized that access to input markets will positively correlate with all types of food processing plants but that this relationship will be more important for supply-oriented processors. It is also hypothesized that supply-oriented firms will be more likely to locate in non-metropolitan counties or counties with relatively more agricultural farmland.

Firms enter product markets to distribute final goods with the goal of minimizing distribution costs. Product markets are also the source of final demand for food processors (Henderson and McNamara 2000). Market potential captures effective demand relative to the supply of competing manufactured goods. Larger markets can be served by taking advantage of lower transportation costs, thereby increasing competitiveness. It is hypothesized that product markets will have a positive relationship with all types of food manufacturers. But proximity to product markets is hypothesized to be more important for demand-oriented food processing firms because the operation costs of these firm types are typically dominated by distribution of final products (Capps, Fuller, and Nichols 1988; Connor and Schiek 1997). It is also hypothesized that demandoriented firms will be more likely to locate in or near metropolitan counties.

The sum of crop and livestock receipts per county acres (AGRI) and the percent of cropland in a county (PERFARM) measure input market effects on the site selection decision. Per capita income (PCI) and the population (POP) of each county measure product market effects on food manufacturing location (Table 1).

\subsection{Labor Availability and Quality (L)}

Manufacturing productivity depends on labor availability. A deep labor pool requires less recruiting and provides a more diversified work force. A diversified work force increases the likelihood of acquiring workers with the necessary skill sets to fill positions at all levels of production. Plants in areas with small quantities of labor face more recruitment and turnover problems. It is hypothesized that a positive relationship exists between food processors' location decisions and labor availability. This is expected to be true of all types of food manufacturing establishments.

Labor quality also affects manufacturing productivity (McNamara, Kriesel, and Deaton 1988). Higher quality workers are generally more productive. Increased productivity leads to higher output at the same or lower costs, thus increasing plant profitability. In lieu of increasing demand for a wide array of labor skill sets, it is hypothesized that high-quality labor will be positively associated with food manufacturing location. 
Labor costs directly influence production costs and plant profits. Places with lower labor costs have lower operating costs, increasing the attractiveness of the area for manufacturing (Smith, Deaton, and Kelch 1978; Schmenner, Huber, and Cook 1987; McNamara, Kriesel, and Deaton 1988). It is hypothesized that labor costs will be negatively correlated with manufacturing location for all food processors.

Four variables were used to measure the effects of labor availability, labor quality, and labor cost on the site selection decision (Table 1). The 2000 average annual manufacturing wage per worker in each county measures labor cost effects (MWAGE). The percent of individuals over the age of 25 with a high school diploma in each county captures labor quality effects (HIGH). The 2000 county unemployment rate proxies the available labor pool (UNEMP), and the percent of the labor force employed in the technology or professional sectors in a given county measures the effects of information technology on firm location (EMP54).

\subsection{Infrastructure (I)}

Infrastructure consists of the physical components of an economy that support the surrounding community and business activities by increasing access to regional, national, and international markets. Infrastructure includes transportation networks, land availability, access to waterways, recreational amenities, and educational institutions. These attributes are hypothesized to increase the attractiveness of a site and the probability of a food manufacturer locating in a given county.

Smith, Deaton, and Kelch (1978); Woodward (1992); and Rainey and McNamara (1999) looked at infrastructure effects at the county level, all finding that it was a significant and positive determinant of plant location choice. Bartik $(1985,1989)$; Glickman and Woodward (1988); and Coughlin, Terza, and Arromdee (1991) found infrastructure effects on manufacturing location at the state level to be significant and positive. Goetz (1997) found infrastructure to be a significant but negative location determinant at the county level. Henderson and McNamara (2000) found infrastructure at the county level to be a positive and significant factor influencing food processor plant location.

Land area and availability is also part of infrastructure. Firms choose a site location that has land available for current projects and possible future expansions (Henderson and McNamara 1997). The probability of a food processor locating operations in a given area depends on the number of potential sites. The larger the county, the better its chance of having a higher profit site (Bartik 1985, 1989; Woodward 1992). It is hypothesized that land availability will have a positive influence on the site selection decision.

The natural amenities associated with a particular place may be attractive to managers faced with the decision to locate operations in a particular region. However, places typically associated with outdoor beauty, scenic vistas, or places considered prime recreation spots may not be attractive to food processors seeking access to product, input, or labor markets. For example, demand-oriented food processors are more likely to locate 
in densely populated metropolitan counties. Or supply-oriented food manufactures may likely choose to locate operations near agricultural inputs. Counties endowed with agricultural resources are usually located on land not generally recognized as scenic (i.e., good agricultural land is typically located on flat spaces without many remarkable topographic features) (Whitener and McGranahan 2003). We test this hypothesis that access to amenities influences plant location decisions. The expected sign is ambiguous.

Educational institutions influence plant location decisions by producing workers with improved skill sets and abilities (Smith, Deaton, and Kelch 1978; Henderson and McNamara 1997). As technology adoption and innovation continue to co-evolve in manufacturing, more educated workers and the capacity to re-equip workers with new skill sets are usually required to remain competitive (McGranahan 1998). Firms looking for a better-educated workforce favor locations with access to educational institutions or training facilities. It is hypothesized that educational institutions will be positively related with food processing plant location for all types of processors.

Five variables were used to measure the effects of infrastructure on site-selection: (i) the presence of an interstate in a county (INTER); (ii) county land area in square miles (LAND, as a proxy of site availability); and (iii) the presence of junior college, business school, or computer school in a county (EDUC, as a proxy of labor quality and potential for skill development); (iv) county adjacency to navigable rivers (RIVER), and (v) county endowment of natural amenities (AMENITY) (Table 1). ${ }^{3}$

\subsection{Fiscal Determinants (F)}

Fiscal policy includes the tax policies and expenditure patterns of states and counties. Fiscal policy influences plant locations by providing public service benefits and imposing taxes to finance these benefits (Henderson and McNamara 1997). Higher state spending is a benefit, but manufacturers refrain from locating in states with high corporate taxes (Goetz 1997). Fiscal policy expenditures directed to educational facilities, worker training, school systems, public services, and infrastructure development can lower the costs of production and increase the prospect of plant profitability (Smith, Deaton, and Kelch 1978; Bartik 1989; Kriesel and McNamara 1991; Henderson and McNamara 1997).

Bartik $(1985,1989)$ measured fiscal policy affects on manufacturing location decisions at the state level and found them to be negative and significant. Kriesel and McNamara (1991), and Rainey and McNamara (1999) found fiscal policy factors at the county level to be significant and negative. Coughlin, Terza, and Arromdee (1991) and Woodward (1992) examined fiscal policy factors at the state level for foreign direct investment. Both of these studies found fiscal policy to be a negative and significant determinant of plant location. Goetz (1997) analyzed fiscal policy factors in his analysis of food processing plant location at the state and county levels. The determinant was found to be significant and negative in the county analysis, but insignificant at the state

\footnotetext{
${ }^{3}$ Rivers can be used for transporting inputs or final products, but they may also have scenic value.
} 
level. Henderson and McNamara (2000) used county per capita property taxes divided by total county expenditures per capita to measure the effects of fiscal policy on firm location decisions. In that study, fiscal policy was found to have a negative effect on plant location choice.

County-level per capita property taxes over total county expenditures per capita were used to measure fiscal effects on the site location decision in this study (TXEXC) (Table 1). It is expected that this measure will be negatively correlated with food processor location choice.

\subsection{Agglomeration Economies (A)}

Agglomeration is the accumulation of business activity in and around a specific geographic area. Agglomeration economies are formed when firms cluster together in a region (Barkley 1995). By-products of agglomeration economies are information, ownindustry, supply-side, and demand-side spillover effects between firms (Cohen and Paul 2005). Other effects include reduced transportation costs of inter-firm trade, increased firm diversity, and product differentiation (Henderson 1994). Businesses agglomerate to access external services at lower costs, to gain access to a base of workers with specialized skills, and to reduce costs of infrastructure provision (Richardson 1973; Henderson and McNamara 1997). The concentration of activity in a particular area usually leads to a larger labor pool with skills needed by that industry (Rainey and McNamara 1999). Agglomeration economies also represent the cost savings gained by firms locating in communities with a relatively large concentration of other firms (Richardson 1973; Kriesel and McNamara 1991; McNamara, Kriesel, and Rainey 1995; Henry and Drabenstott 1996; Rainey and McNamara 1999). Agglomeration factors are hypothesized to positively correlate with the location decision of all types of food processing plants.

Four variables were used to measure agglomeration effects at the county level: (i) the percent change in manufacturing establishments between 1998 and 2000 (CHGMFG), (ii) the number of food manufacturing establishments relative to the total number of business establishments in a given county (MFGS), (iii) the percent of the workforce employed by the manufacturing sector (MEMPL) (Gabe 2005; Lambert, McNamara, and Garrett 2006), and (iv) the spatial lag of site selection activity between counties.

Firms tend to spatially concentrate depending on the previous location of other firms in the same industry. Alfred Marshall explained the pattern of firm clustering as the result of external economies operating as a centripetal force characterized by knowledge spillovers, thick markets, and forward-backward linkages (Fujita, Krugman, and Venables 1999). Spatial lag models have been used to model these effects due to economic agents interacting across space (Moreno et al. 2004). In this study, a limited dependent variable (LDV) conditional spatial lag model is specified to measure the effects location decisions of firms in one county have on neighboring counties (Anselin 2002). The conditional spatial lag specification $\mathbf{y}=\rho \mathbf{W} \mathbf{y}+\mathbf{X} \boldsymbol{\beta}+\boldsymbol{\varepsilon}$, with $\boldsymbol{\varepsilon} \sim \mathrm{N}(\mathbf{0}, \boldsymbol{\Omega})$ 
models the probability that a given county will attract food manufacturing investment. The spatially lagged dependent variable (Wy) captures how much county $i$ 's probability of attracting food manufacturing investment is linked to neighboring counties' likelihood of bringing in outside investment, and $\mathbf{W}$ is a spatial weighting matrix identifying the network connecting economic agents. The spatial autoregressive lag coefficient $(\rho)$ measures the influence of firms located in surrounding counties on the probability that a food manufacturing firm will locate in a given county. In the context of this study, it is interpreted as the fourth measure of agglomeration. ${ }^{4}$ The hypothesis is that a county is more likely to attract food manufacturing investment when its neighbors have similar attributes conducive to attracting food processors.

\section{EMPIRICAL METHODS}

Spatial LDV models have received recent attention in the spatial econometric literature (c.f., Anselin, Florax, and Rey 2004 for a review). There are several methods available to estimate LDV models. One approach tackles the problem using General Method of Moments (Fleming 2004). Another approach uses an expectation maximization algorithm (McMillen 1992). Still other approaches have used recursive importance sampling techniques (Beron and Vijverberg 2004). A Bayesian simulation approach using the Gibbs sampler is taken here to estimate the spatial probit model (LeSage 1997, 2000; Holloway, Shankur, and Rahman 2002). ${ }^{5}$

The spatial weighting matrix was a row-standardized, positive semi-definite matrix that identified neighborhoods of counties. Polygon data was used to represent the 1,121 counties in the sample, and a contiguity matrix based on the "queen" criterion was used to identify neighborhoods of counties that shared borders (Anselin 1988). Polygon data retains information about local networks because they define the boundaries that make up administrative units. Instead of placing equal weight on neighboring counties, the percent of the total perimeter of a county shared with a neighboring county was used to weight observations.

The empirical model is a first-order linear approximation of the site location function $(\mathrm{S})$ :

$$
\operatorname{Pr}\left[S_{i}=1\right]=f\left(\sum_{j, i \neq j} w_{i j} S_{j}, \mathrm{M}_{i}, \mathrm{~A}_{i}, \mathrm{I}_{i}, \mathrm{~L}_{i}, \mathrm{~F}_{i}, \mathrm{~d}_{R} ; \theta\right)+\varepsilon_{i}
$$

\footnotetext{
${ }^{4}$ In their food manufacturer location study, Cohen and Paul (2005) used a spatial error model to measure the influence of unobserved effects of agglomeration economies on food processor clustering: $\mathbf{y}=\mathbf{X} \boldsymbol{\beta}+(\mathbf{I}-\rho \mathbf{W})^{-1} \boldsymbol{\varepsilon}$. By re-organizing the spatial lag model, it is easy to see how unobserved factors are linked to the dependent variable by way of the spatial multiplier $(\mathbf{I}-\rho \mathbf{W})^{-1}$. The model specification can be re-arranged as $\mathbf{y}=(\mathbf{I}-\rho \mathbf{W})^{-1} \mathbf{X} \boldsymbol{\beta}+(\mathbf{I}-\rho \mathbf{W})^{-1} \boldsymbol{\varepsilon}$. In this specification, a decision at the ith location $\left(y_{i}\right)$ is systematically linked to all other $x_{\mathrm{i}} \mathrm{s}$ and is determined by the error term at all other locations (Anselin 2002).

${ }^{5}$ The estimates are based on 10,000 draws with a burn-in period of 5,000.
} 
where $\theta=\left[\rho, \beta, \delta_{\mathrm{R}}\right]^{\prime}, \beta$ is a $k$ by 1 vector of parameters relating location determinants in county $i$ to site selection events, $\rho$ is a spatial autoregressive term explaining surrounding county effects on firm location choice, $w_{i j}$ are elements in $\mathbf{W}$ identifying neighboring counties, $\varepsilon_{i} \sim \mathrm{N}\left(0, \sigma_{i}{ }^{2}\right)$, and $\delta_{R}$ are coefficients of regional dummy variables restricted as $\Sigma_{R} \delta_{R}=0 .{ }^{6}$ Accepting the joint hypothesis that the regional dummy coefficients are not different from zero is evidence that the first and second stages of the selection process are independent. ${ }^{7}$ Rejection of this hypothesis makes inference about the influence of local county determinants on site selection difficult because it implies that regional-level effects are confounded with local attributes. In the event that the null hypothesis cannot be rejected, the regional coefficients are removed from the model.

Equation 1 was estimated using a data set that combined all food processor location announcements. Equation 1 was also estimated after disaggregating the combined data set according to the firm typology corresponding with footloose, supply-, demand-oriented food processors (Table 1).

\subsection{Spatial Cluster Analysis}

Spatial cluster analysis was performed using Local Indicators of Spatial Association (LISA, Anselin 1995) to determine whether the pattern of predicted location probabilities formed agglomeration clusters or broader, interconnected regions that exhibited greater likelihood of attracting food manufacturing investment relative to other areas. We interpret clusters of counties with high probabilities of attracting food manufacturing investment as signaling the presence of local agglomeration economies in a broader regional context. In this sense, agglomeration economies are groups of counties whose probabilities of attracting food manufacturing investment are significantly greater than those of the global population of counties. The expected pattern is therefore one of positive spatial autocorrelation.

\section{RESULTS AND DISCUSSION}

The likelihood ratio scores for all models (footloose, supply, demand, and combined firm location announcements) indicated that inclusion of the location determinants provided a better fit than the restricted models (i.e., $\boldsymbol{\theta}=\mathbf{0}$; no determinants at all), although the Estrella's adjusted $\mathrm{R}^{2}$ for all models were modest (Table 2). With respect to predicting firm location, all models performed quite well. Spatial lag dependence was significant, albeit moderate, across all models $\left(\mathrm{H}_{0}: \rho=0\right.$; likelihood ratio test $=36,80$, 46, 95 for the combined model, demand, supply, and footloose models, respectively;

\footnotetext{
${ }^{6}$ The Bayesian probit model allows for the estimation of heteroskedastic effects that may be associated with each county.

${ }^{7}$ Heckman's sample selection model would be an alternative, albeit more complicated, approach to test this assumption, given the spatial nature of the problem. This approach is left for future research.
} 
TABLE 2

Probit Firm Location Results for All Firm Types in the Midwest-Southern Region

\begin{tabular}{|c|c|c|c|c|}
\hline Variable & All Firms & $\begin{array}{l}\text { Supply } \\
\text { Oriented }\end{array}$ & $\begin{array}{l}\text { Demand } \\
\text { Oriented }\end{array}$ & $\begin{array}{c}\text { Footloose } \\
\text { Oriented }\end{array}$ \\
\hline CONSTANT & $-4.12(-3.58)^{* 1}$ & $-2.82(-2.94) *$ & $-3.01(-2.76)^{*}$ & $-4.11(-3.37)^{*}$ \\
\hline CHGMFG & $0.14(0.31)$ & $0.26(0.55)$ & $-0.10(-0.18)$ & $0.02(0.04)$ \\
\hline AGRI & $0.02(1.14)$ & $0.03(2.08)^{* *}$ & $-0.002(-0.12)$ & $-0.01(-0.34)$ \\
\hline POP & $0.02(1.63)$ & $0.02(1.85)^{* *}$ & $0.02(1.65)^{* *}$ & $0.02(1.78)^{* *}$ \\
\hline PCI & $0.10(3.13)^{*}$ & $0.06(2.07)^{*}$ & $0.11(3.49)^{*}$ & $0.05(1.36)$ \\
\hline MFGS & $55.52(3.20)^{*}$ & $55.38(3.48)^{*}$ & $24.17(1.13)$ & $21.77(0.99)$ \\
\hline MEMPL & $2.06(2.52)^{*}$ & $1.38(1.88)^{* *}$ & $0.15(0.17)$ & $1.71(1.85)^{* *}$ \\
\hline PERFARM & $0.33(0.74)$ & $0.61(1.66)^{* *}$ & $0.45(1.05)$ & $0.01(0.03)$ \\
\hline LAND & $0.01(2.01)^{*}$ & $0.01(2.80)^{*}$ & $0.004(0.66)$ & $0.004(0.60)$ \\
\hline INTER & $0.34(2.48)^{*}$ & $0.17(1.28)$ & $0.31(1.91)^{* *}$ & $0.33(1.83)^{* *}$ \\
\hline RIVERS & $0.03(0.18)$ & $-0.04(-0.28)$ & $-0.08(-0.52)$ & $0.11(0.63)$ \\
\hline AMENITY & $-0.10(-1.38)$ & $-0.03(-0.58)$ & $0.02(0.24)$ & $-0.08(-1.10)$ \\
\hline EDUC & $0.39(2.61)^{*}$ & $0.16(1.11)$ & $0.45(2.47)^{*}$ & $0.29(1.58)$ \\
\hline MICROPOLITAN & $0.12(0.71)$ & $0.41(2.41)^{*}$ & $-0.14(-0.76)$ & $0.06(0.31)$ \\
\hline RURAL & $-0.23(-1.14)$ & $-0.02(-0.12)$ & $-0.31(-1.34)$ & $-0.04(-0.18)$ \\
\hline UNEM & $0.02(0.63)$ & $0.04(1.12)$ & $0.03(0.81)$ & $0.03(0.71)$ \\
\hline HIGH & $-1.08(-0.67)$ & $-2.22(-1.67)^{* *}$ & $-2.41(-1.56)$ & $0.46(0.28)$ \\
\hline MWAGE & $-0.001(-0.20)$ & $-0.002(-0.39)$ & $-0.002(-0.25)$ & $-0.001(-0.09)$ \\
\hline EMP54 & $-0.23(-0.04)$ & $2.13(0.37)$ & $-3.10(-0.48)$ & $-3.45(-0.50)$ \\
\hline TXEXC & $0.04(0.12)$ & $-0.05(-0.15)$ & $-0.04(-0.11)$ & $-0.16(-0.45)$ \\
\hline$\rho$ & $0.06(1.97)^{*}$ & $0.08(2.10)^{*}$ & $0.07(1.94)^{* *}$ & $0.06(1.87)^{* *}$ \\
\hline $\begin{array}{l}\% \text { Correctly } \\
\text { predicted }\end{array}$ & $79 \%$ & $80 \%$ & $73 \%$ & $81 \%$ \\
\hline Log likelihood & -439 & -244 & -205 & -204 \\
\hline $\begin{array}{l}\text { Estrella's adjusted } \\
\text { R-squared }{ }^{2}\end{array}$ & 0.22 & 0.21 & 0.14 & 0.11 \\
\hline
\end{tabular}

degrees of freedom $(\mathrm{df})=1$ ). Based on these diagnostics, equation 1 was estimated using the spatial probit specification.

\subsection{Wald Test for First Stage Regional Effects}

The coefficients associated with the regional variables should not be significant if the assumption of independence between first and second stage location decisions is tenable. 
A Wald statistic $(\hat{W})$ was used to test this joint hypothesis for each model $\left(\mathrm{H}_{0}: \boldsymbol{\delta}=\mathbf{0}\right.$, with $\boldsymbol{\delta}$ the regional coefficient vector). The null hypothesis that regions did not influence the second stage decision of firm site-selection was accepted for the footloose, demand-, and supply-oriented models at the 5 percent level $(\hat{\mathrm{W}}=6.92,2.09,9.82$, demand-, supply-oriented, and footloose firms, respectively, $\mathrm{df}=13$ ). But when all firms were combined, the assumption that the first- and second-stage decisions were independent was untenable $(\hat{\mathrm{W}}=29.65, \mathrm{P}=0.008)$. These results suggest that the regional coefficients may be omitted in the demand, supply, and footloose models. But to interpret the ceteris paribus effects of location determinants in the model pooling all of the location announcements, the regional variables were retained since they were significant.

\subsection{Market Determinants}

In general, counties that facilitate access to input and product markets have a better chance of attracting food manufacturing investment. Access to input supply was important in the supply-oriented model, supporting the hypothesis that supply-oriented food manufacturers tend to put more weight on input availability. This result is consistent with the McNamara and Henderson (1997) study of food manufacturers in the Corn Belt region. Holding other factors constant, a 10 percent increase in per acre agricultural revenue corresponded with a 1.8 percent increase in the probability of attracting investments from supply-oriented food manufacturers (Table 3). Counties providing access to product markets had a better chance of attracting investment from all firm types. Per capita income was an important location determinant for demand- and supply-oriented firms. Given a 1 percent increase in per capita income, the probability of attracting any type of food manufacturing investment increased by more than 1 percent. County population also had a positive effect on the probability of attracting footloose, demand-, and supply-oriented firms. All else equal, a 10 percent increase in population corresponded with an increase of 2 percent or more in the likelihood of attracting these firm types.

\subsection{Agglomeration Determinants}

Agglomeration determinants were significant for supply-oriented firms in particular and all firms in general, which is consistent with the Cohen and Paul (2005) finding that food manufacturers tend to locate in areas where there are high concentrations of other manufacturing firms (Table 3). A 10 percent increase in the share of the workforce employed in manufacturing corresponded with a 5.7 percent increase in the probability of attracting food manufacturing investment. Likewise, counties where the number of food manufacturing establishments was large relative to all business establishments in that county were more likely to attract food manufacturing investment. Given a 10 percent increase in the share of food manufacturers in a given county, the probability of attracting new food manufacturing investment increased by 3 percent. 
TABLE 3

Elasticities of Food Manufacturer Location Determinants for Midwest-Southern States ${ }^{1}$

\begin{tabular}{|c|c|c|c|c|}
\hline $\begin{array}{l}\text { Location Determinant } \\
\text { AGRI (M) }\end{array}$ & $\underline{\text { All Firms }}$ & $\frac{\text { Supply Oriented }}{0.18 \%}$ & Demand Oriented & Footloose \\
\hline PCI (M) & $3.34 \%$ & $2.29 \%$ & $4.92 \%$ & \\
\hline POP (M) & . & $0.20 \%$ & $0.22 \%$ & $0.30 \%$ \\
\hline PERFARM (M) & & $0.51 \%$ & $0.43 \%$ & $0.01 \%$ \\
\hline $\operatorname{MFGS}(\mathrm{A})$ & $0.33 \%$ & $0.38 \%$ & . & . \\
\hline MEMPL (A) & $0.57 \%$ & $0.43 \%$ & . & . \\
\hline HIGH (L) & 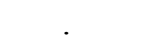 & $-2.87 \%$ & . & . \\
\hline LAND (I) & $0.63 \%$ & $0.76 \%$ & & . \\
\hline INTER $(\mathrm{I})^{2}$ & $88.16 \%$ & & $96.1 \%$ & . \\
\hline $\operatorname{MIC}(\mathrm{I})^{2}$ & & $7.95 \%$ & & . \\
\hline $\operatorname{EDUC}(\mathrm{I})^{2}$ & $9.61 \%$ & & $5.33 \%$ & . \\
\hline
\end{tabular}

Notes: ${ }^{1}$ Includes variables significant at the $10 \%$ level or lower. ${ }^{2}$ The percent change for the discrete variables are the probability of a county not having an attribute to one of having that attribute. Source: authors' estimates.

\subsection{Infrastructure Determinants}

Larger counties with interstate access and junior colleges, business schools, or other educational facilities were more likely to attract food manufacturing investment by all firm types (Table 3). Access to rivers or abundance in natural amenities appeared to have no effect on the likelihood of attracting food manufacturing investment. The presence of an educational facility increased the probability of attracting food manufacturing investment from all firm types and firms with cost structures consistent with the Connor and Schiek (1997) demand-oriented firm type. Holding other factors constant, counties with a junior college or business school were 5 percent and 10 percent more likely to attract all food manufacturer types and demand-oriented firm investment, respectively. Counties with interstates were 88 percent more likely to attract food manufacturing investment by all types. Interstate access appears to be important for demand-oriented firms, which is also consistent with the notion that minimizing distribution costs is a primary objective of this food processor type. Micropolitan counties appear to be competitive with respect to attracting supply-oriented food manufactures. These non-metro counties are economically tied to larger urban centers or agglomeration economies with significant into/out-of commuting patterns. Counties with relatively more land in agricultural production also appear to be more competitive with respect to attracting footloose and supply-oriented processors.

\subsection{Labor Determinants}

The proxy variable for labor quality (HIGH) was negative and significant in the supply-oriented model but insignificant in all other models. The negative effect on supply-oriented location decisions may suggest that firms with cost structures dominated 
by input acquisition expenses may prefer to hire lower-skilled workers. A low-skilled workforce may also correlate with lower wages, holding other factors constant (Gibbs, Kusmin, and Cromartie 2005). In some food processing operations (for example, the catfish or meat packing industries), highly educated workers may not be too important with respect to slaughter and processing. This conclusion corresponds with the predicted location probabilities associated with supply-oriented firms, where there is significant clustering in the catfish belt along the Mississippi (Figure 1). Many of these counties are also persistent poverty or low-education counties.

Labor cost was not a significant determinant with respect to site selection. Labor cost may have been a stronger determinant with respect to plant choice in the 1980s. But in lieu of recent economic trends, labor productivity has increased with the widespread use of information technologies. The insignificance of this variable suggests that other factors are more important to food manufacturers with respect to site selection. Firms seeking low-skill labor may be more inclined to look offshore or hire migrant workers more willing to work for lower wages. In general, for food manufacturers locating in the midwest and southern U.S., labor cost does not appear to be an important location factor.

The variable EMP54 is the percent of the workforce employed in the technology sector as defined by the North American Industrial Classification System. Given that today's economy may be characterized as one dominated by the integration of information technology into all aspects of production, it was hypothesized that this variable would measure the importance of professional and technical services on firm location choice. The insignificance of this variable suggests that food manufacturing firms may not place a premium on "high-tech" innovations compared to other businesses in the manufacturing sector.

\subsection{Fiscal Determinant}

Fiscal policy, as measured by per capita property taxes divided by total county expenditures per capita, was not associated with food processor site selection. Fiscal policy is most likely not an issue for food manufacturing firms in particular and the manufacturing sector in general because firms may negotiate long-term abatements on capital taxes with county governments.

\subsection{Spatial Clusters of Competitive Counties}

Local Indices of Spatial Association were estimated to directly compare the local attributes of counties comprising high-probability clusters with counties not associated with location clusters (Figure 1). In all cases, Moran's I was significant at the 5 percent level and greater than 0.35 , indicating a pattern of positive spatial correlation. Demandoriented food manufacturers form clusters around counties with larger populations, counties closer to metropolitan areas, and counties with reliable transport infrastructure. Supply-oriented firms tend to cluster near agglomeration economies or near input sources. The proportion of counties associated with the high-probability clusters classi- 
fied as metropolitan, non-metro micropolitan, non-metro rural counties are presented in Figure 2. Across all firm types, most of the counties making up the high-probability supply-oriented firms is similar to the results combining all firms. It appears that nonmetropolitan counties with economic ties to larger urban centers are slightly more competitive with respect to attracting supply-oriented firms than are demand-oriented or footloose firms. Rural, non-core counties appear not to be competitive at all with respect to attracting demand-oriented food manufacturers.

The location determinants associated with the high-probability clusters were compared to all other counties using $t$ tests (Table 4). These comparisons provide a way to quantify the differences between the attributes of counties predicted to be in highprobability clusters with those that are not. When all firm types (column 1, Table 4) were considered, counties located in high-probability clusters were endowed with more of the clusters were metropolitan counties. However, the distribution associated with the factors

Percent of counties in cluster

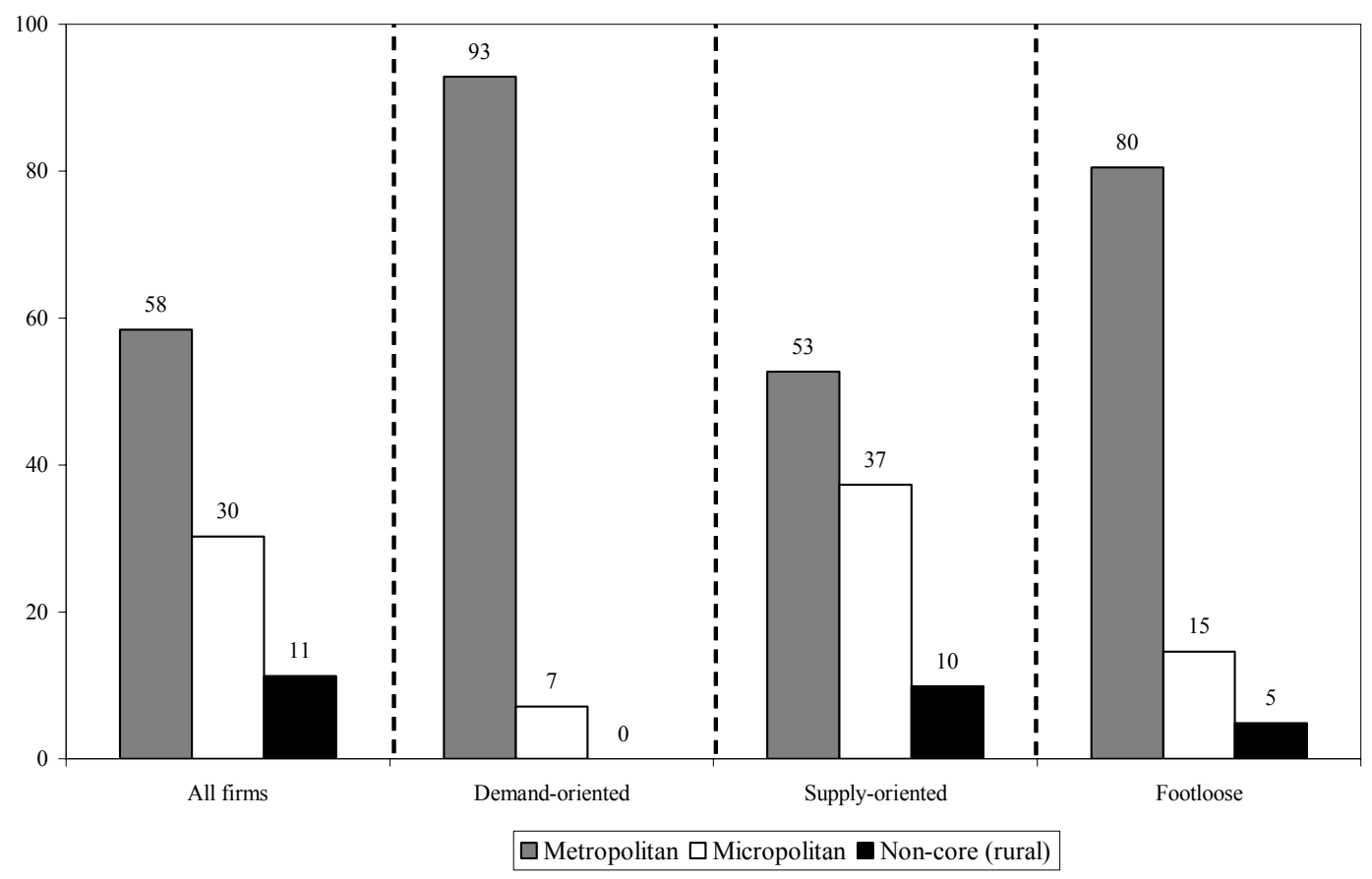

FIGURE 2. Distribution of Metropolitan, Micropolitan, and Rural (Non-Core) Counties in Midwestern-Southern States Food Manufacturer Location Clusters

Notes: Numbers do not sum top 100 due to rounding.

Source: authors' estimates. 
TABLE 4

Mean Comparison of Location Determinants between Counties Located in High Probability Clusters with All Other Counties ${ }^{1}$

\begin{tabular}{|c|c|c|c|c|}
\hline $\begin{array}{c}\text { Location } \\
\text { Determinant }\end{array}$ & All Firms & $\begin{array}{l}\text { Demand- } \\
\text { Oriented }\end{array}$ & $\begin{array}{l}\text { Supply- } \\
\text { Oriented }\end{array}$ & $\begin{array}{c}\text { Footloose } \\
\text { Firms }\end{array}$ \\
\hline CHGMFG & $1.67 \% *$ & $2.22 \% *$ & $2.43 \% *$ & $2.33 \% *$ \\
\hline AGRI & $136^{*}$ & 69 & $201 *$ & 30 \\
\hline POP & $129,901 *$ & $234,474 *$ & $139,558^{*}$ & $200,074 *$ \\
\hline PCI & $4,965^{*}$ & $8,046^{*}$ & $5,690^{*}$ & $7,378^{*}$ \\
\hline MFGS & $0.13 \% *$ & $-0.07 \% *$ & $0.08 \% *$ & $0.03 \%$ \\
\hline MEMPL & $4.99 \% *$ & $-1.59 \%$ & $3.33 \% *$ & $0.66 \%$ \\
\hline PERFARM & $16.55 \% *$ & $1.20 \%$ & $11.37 \% *$ & $8.46 \% *$ \\
\hline LAND & $28,685^{*}$ & $-26,346$ & -466 & $-40,433^{*}$ \\
\hline EDUC & $40 \% *$ & $56 \%$ & $37 \%$ & $46 \%$ \\
\hline UNEM & $-0.58 \% *$ & $-1.58 \% *$ & $-0.99 \% *$ & $-1.42 \% *$ \\
\hline HIGH & $7.70 \% *$ & $10.34 \% *$ & $8.09 \% *$ & $10.70 \% *$ \\
\hline MWAGE & $9,948^{*}$ & $12,325^{*}$ & $9,910^{*}$ & $12,827^{*}$ \\
\hline EMP54 & $0.84 \% *$ & $1.83 \% *$ & $0.99 \% *$ & $1.53 \%$ * \\
\hline TXEXC & $-0.012 *$ & $-0.004 *$ & $-0.008^{*}$ & $-0.023^{*}$ \\
\hline \multicolumn{5}{|c|}{ 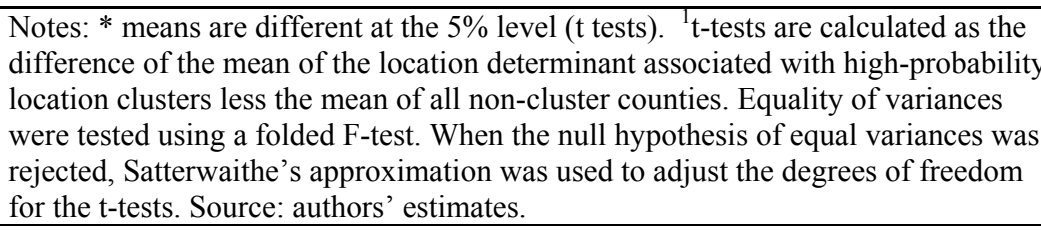 } \\
\hline
\end{tabular}

associated with product markets, agglomeration economies, and infrastructure but exhibited lower unemployment rates and lower property taxes per capita/county expenditures per capita ratios than all other counties. The presence of educational facilities appears to be an important location determinant for demand-oriented firms, but the number of counties with educational facilities in the demand-oriented high-probability clusters was not significantly different from counties located outside of the clusters. Per acre agricultural receipts were higher for counties in the high-probability clusters compared to all other counties when supply-oriented firms were considered. This was not the case focusing on footloose and demand-oriented food manufacturers.

\section{CONCLUSIONS}

Local community attributes influence location choices of firms. Population, a measure of agglomeration due to urbanization economies and product markets, commuting volume, labor quality, and transportation infrastructure are key location determinants for food manufacturing in the midwest-southern states. Returns on investment may be high 
for non-metropolitan counties planning to recruit food manufacturers if (i) they are economically tied to metropolitan counties or urban centers, as evidenced by predictable commuting patterns; (ii) they have access to transport infrastructure; and (iii) they target supply-oriented firms. Rural counties do not appear to be competitive with respect to attracting food manufacturers whose costs structures are dominated by distribution costs or reliance on product markets and business services relative to other non-metropolitan counties. Footloose and demand-oriented food processors tend to select plant locations in and around urban areas or in places that provide access to product markets or agglomeration economies. Supply-oriented firms might select non-metropolitan sites that provide access to agricultural inputs, but they might also choose to locate in areas where the workforce is less skilled.

Counties providing access to agglomeration economies, product markets, transportation networks, and agricultural resources are better-positioned to use food manufacturing recruitment as an economic development strategy. Non-metropolitan counties not endowed with these attributes might consider alternative investment strategies. The prospects of attracting manufacturing investment depend on factors that may or may not be directly influenced by specific economic development strategies. Policy makers might investigate public infrastructure financing and its relation with manufacturing activity. While it might be difficult to garner funding for construction of an interstate, county planners may be able to provide access highways or widen existing byways to improve transportation on a cost-share basis through negotiations with potential investors.

Many factors cannot be directly influenced, but some can be adjusted. Community leaders might consider fostering environments that encourage workers to update their skills by promoting educational opportunities through business schools or local community colleges. It is also difficult to envision every county constructing a junior college or business school. Nonetheless, counties with such training facilities appear to be more competitive with respect to attracting food manufacturing investment.

In their study of worker occupational skill level and food processors, Schluter and Lee (2002) ask, "Have rural areas benefited from the reduced skills required of labor in U.S. processed food trade?" Of course, the answer depends on one's point of view. The economic base of the community will grow with the addition of a food manufacturer. Opportunities for the non-basic economic sector will expand as consumer spending increases. Commuter migrants will fill in gaps to meet labor shortages at the new facility. This will increase traffic and decrease the potential benefits from higher consumer spending. The local education system may be strained by migrants relocating in the community. Inevitably, some community members will welcome growth and change while others will not.

Finally, rural communities already endowed with a manufacturing base may find that spending scarce development resources on projects geared toward retaining businesses will yield better payoffs in the future. Indeed, the ability of a community to retain businesses through economic downturns and recoveries may send a strong signal to 
potential investors that local conditions are favorable (Barkley 2001). Such a strategy might include creating an environment conducive to the growth of local service and trade businesses, improvement of social capital infrastructure, development of recreation and tourism, and encouragement of entrepreneurship and small business development.

\section{REFERENCES}

Amiti, M., 1998. "New Trade Theories and Industrial Location in the EU: A Survey of Evidence," Oxford Review of Economic Policy 14(2), 45-54.

Anselin, L., 1988. Spatial Econometrics: Methods and Models. Kluwer Academic Publishers: London. , 1995. "Local Indicators of Spatial Association," Geographical Analysis 27, 93115.

, 2002. "Under the Hood: Issues in the Specification and Interpretation of Spatial Regression Models," Agricultural Economics 27, 247-267.

Anselin, L, R.J.G.M. Florax, and S.J. Rey, 2004. Advances in Spatial Econometrics: Methodology, Tools and Applications. Springer: Berlin.

Barkema, A.D., M. Drabenstott, and J. Stanley, 1990. "Processing Food in Farm States: An Economic Development Strategy for the 1990s," Economic Review 75(4), 5-23, Federal Reserve Bank of Kansas City.

Barkley, D.L., 1995. "The Economics of Change in Rural America," American Journal of Agricultural Economics 77, 1252-1258. , 2001. "Employment Generation Strategies for Small Towns: An Overview of the Alternatives," REDRL Research Report 09-2001-02, Clemson University, available at http://cherokee.agecon.clemson.edu/redrl_rpt2.pdf.

Bartik, T.J., 1985. "Business Location Decisions in the United States: Estimates of the Effects of Unionization, Taxes, and Other Characteristics of States," Journal of Business and Economic Statistics 3(1), 14-22.

, 1989. "Small Business Start-Ups in the United States: Estimates of the Effects of Characteristics of States," Southern Economic Journal 55(4), 1004-1018.

Benirschka, M. and J.K. Binkley, 1994. "Land Price Volatility in a Geographically Dispersed Market," American Journal of Agricultural Economics 76(2), 185-195.

Beron, K.J. and W.P.M Vijverberg, 2004. "Probit in a Spatial Context: A Monte Carlo Analysis," in L. Anselin, R.J.G.M. Florax, and S.J. Rey (eds.), Advances in Spatial Econometrics: Methodology, Tools and Applications. Springer: Berlin.

Black, S.E. and L.M. Lynch, 2000. "What's Driving the New Economy: The Benefits of Workplace Innovation," Working paper 7479, National Bureau of Economic Research.

Capps, O. Jr., S.W. Fuller, and J.P. Nichols, 1988. "Assessing Opportunities in Food and Fiber Processing and Distribution," American Journal of Agricultural Economics $70(2), 462-468$.

Cohen, J.P. and C.M. Paul, 2005. "Agglomeration Economies and Industry Location Decisions: The Impacts of Spatial and Industrial Spillovers," Regional Science and Urban Economics 35, 215-237. 
Connor, J.M., 1987. "Trends in Indiana's Food and Agricultural Marketing Industries 1963-1982," Purdue University Research Bulletin No. 986.

Connor, J.M. and W. Schiek, 1997. Food Processing: An Industrial Powerhouse in Transition, $2^{\text {nd }}$ ed. John Wiley and Sons: New York.

Coughlin, C.C., J.V. Terza, and V. Arromdee, 1991. "State Characteristics and the Location of Foreign Direct Investment within the United States," The Review of Economics and Statistics 73(4), 675-683.

Fleming, M.M, 2004. "Techniques for Estimating Spatially Dependent Discrete Choice Models," in L. Anselin, R.J.G.M. Florax, and S.J. Rey (eds.), Advances in Spatial Econometrics: Methodology, Tools and Applications. Springer: Berlin.

Fujita, M., P. Krugman, and A.J. Venables, 1999. The Spatial Economy: Cities, Regions, and International Trade. MIT Press: Cambridge.

Gabe, T.M., 2005. "Industry Agglomeration and Investment in Rural Business," Review of Agricultural Economics 27(1), 89-103.

Gibbs, R., L. Kusmin, and J. Cromartie, 2005. "Low-Skill Employment and the Changing Economy of Rural America," Economic Research Report No. 10, USDA-ERS.

Glickman, N.J. and D.P. Woodward, 1988. "The Location of Foreign Direct Investment in the United States: Patterns and Determinants," International Regional Science Review 11(2), 137-154.

Goe, W.R., 2002. "Factors Associated with the Development of Nonmetropolitan Growth Nodes in Producer Services Industries, 1980-1990," Rural Sociology 67(3), 416-441.

Goetz, S., 1997. "State- and County-Level Determinants of Food Manufacturing Establishment Growth: 1987-1993," American Journal of Agricultural Economics 79(3), 838-850.

Henderson, J.R. and K.T. McNamara, 1997. "Community Attributes Influencing Local Food Processing Growth in the U.S. Corn Belt," Canadian Journal of Agricultural Economics 45, 235-250.

, 2000. "The Location of Food Manufacturing Plant Investments in Corn Belt Counties," Journal of Agricultural and Resource Economics 25(2), 680-697.

Henderson, V., 1994. "Externalities and Industrial Development," Cityscape: A Journal of Policy Development and Research 1(1), 75-93.

Henry, M. and M. Drabenstott, 1996. "A New Micro View of the U.S. Rural Economy," Economic Review, Federal Reserve Bank of Kansas City, Second Quarter.

Holloway, G., B. Shankur, and S. Rahman, 2002. "Bayesian Spatial Probit Estimation: A Primer and an Application to HYV Rice Adoption," Agricultural Economics 27, 383 402.

Kriesel, W. and K.T. McNamara, 1991. "A County-Level Model of Manufacturing Plant Recruitment with Improved Industrial Site Quality Measurement," Southern Journal of Agricultural Economics 31(1), 121-127.

Lambert, D., K. McNamara, and M. Garret, 2006. "An Application of Spatial Poisson Models to Manufacturing Investment Location Analysis," Journal of Agriculture and Applied Economics 38(1), 102-115.

Leistritz, F.L., 1992. "Agribusiness Firms: Location Determinants and Economic Contribution," Agribusiness 8(4), 273-286. 
LeSage, J.P., 1997. "Bayesian Estimation of Spatial Autoregressive Models," International Regional Science Review 20(1, 2), 113-129.

2000. "Bayesian Estimation of Limited Dependent Variable Spatial Autoregressive Models," Geographical Analysis 32, 19-35.

Lopez, R.A. and N.R. Henderson, 1989. "The Determinants of Location Choices for Food Processing Plants," Agribusiness 5(6), 619-632.

McGranahan, D.A., 1998. "Patterns in Skills and Manufacturing in Rural and Urban America." Paper presented at Learning Now Skills for an Information Economy, An International Symposium in Regional Technology Strategies, available at http:// www.rtsinc.org/learningnow/mcgranahan.doc.

, 2000. "Boon or Bust? New Technology Manufacturing in Low-Skill Rural Areas," U.S. Department of Agriculture, ERS, available at http://www.ers.usda.gov/Briefing/ Industry/boonorbust.

McMillen, D.P., 1992. "Probit with Spatial Autocorrelation," Journal of Regional Science 32, 335-348.

McNamara, K.T., W.P. Kriesel, and B.J. Deaton, 1988. "Manufacturing Location: The Impact of Human Capital Stocks and Flows," Review of Regional Studies 18(1), 4248.

McNamara, K.T., W. Kriesel, and D.V. Rainey, 1995. "Manufacturing Recruiting as a Rural Development Strategy," in D.W. Sears and J.N. Reid (ed.), Rural Development Strategies. Nelson-Hall: Chicago.

Moreno, R., E. López-Bazo, E. Vayá, and M. Artis, 2004. "External Effects and Cost of Production," in L. Anselin, R.J.G.M. Florax, and S.J. Rey (eds.), Advances in Spatial Econometrics: Methodology, Tools and Applications. Springer: Berlin.

Rainey, D.V. and K.T. McNamara, 1999. "Taxes and Location Decision of Manufacturing Establishments," Review of Agricultural Economics 21(1), 86-98.

Richardson, H.W., 1973. Regional Growth Theory. Wiley: New York.

Schluter, G. and C. Lee, 2002. "Can Rural Employment Benefit From Changing Labor Skills in U.S. Processed Food Trade?" Rural America 17(4), 38-43.

Schmenner, R.W., J.C. Huber, and R.L. Cook, 1987. "Geographic Differences and the Location of New Manufacturing Facilities," Journal of Urban Economics 21(1), 83104.

Smith, E.D., B.J. Deaton, and D.R. Kelch, 1978. "Location Determinants of Manufacturing Industry in Rural Areas," Southern Journal of Agricultural Economics 10(1), 23-32.

Testa, W.A., 1993. "Trends and Prospects for Rural Manufacturing," Federal Reserve Bank of Chicago Economic Perspectives 17(2), 27-36.

Vesecky, M. and D. Lins, 1995. "Factors Influencing Expansion and Contraction Decisions by Illinois Agribusiness Firms," Agribusiness 11(5), 405-413.

Whitener, L. and D. McGranahan, 2003. "Rural America: Opportunities and Challenges," Amber Waves 1(1), 15-22.

Woodward, D.P., 1992. "Locational Determinants of Japanese Manufacturing Start-Ups in the United States," Southern Economic Journal 58(3), 690-708. 